\title{
Suggestions for a Covid-19 Post-Pandemic Research Agenda in Environmental Economics
}

\author{
Robert J. R. Elliott ${ }^{1} \cdot$ Ingmar Schumacher $^{2}$ D $\cdot$ Cees Withagen ${ }^{3}$
}

Accepted: 11 July 2020 / Published online: 4 August 2020

(c) Springer Nature B.V. 2020

\begin{abstract}
In this article we draw upon early lessons from the 2020 Covid-19 crisis and discuss how these may relate to a future research agenda in environmental economics. In particular, we describe how the events surrounding the Covid-19 crisis may inform environmental research related to globalization and cooperation, the green transition, pricing carbon externalities, as well as the role of uncertainty and timing of policy inventions. We also discuss the implications for future empirical research in this area.
\end{abstract}

Keywords Covid-19 · Environmental economics · Research agenda · Green stimulus · Cooperation · Globalization · Green transition

\section{Introduction}

The 2020 Covid-19 crisis has taken many people by surprise, both because few initially expected such a pandemic, but also because only few could have possibly anticipated that such drastic policy responses would be required or were even possible. In particular, at the time of writing, the various lockdowns across the world have already had significant implications not only for economic growth, but also for global supply chains, international cooperation, government policy and the environment. In this paper we discuss some of the lessons that we can already draw from the Covid-19 pandemic, and what they suggest about how we may want to redirect some of our research in environmental economics. Our focus here will be on globalization and cooperation, on the green transition with emphasis

We are grateful to Tasos Xepapadeas for comments.

Ingmar Schumacher

ingmar.schumacher@ipag.fr

Robert J. R. Elliott

r.j.elliott@bham.ac.uk

Cees Withagen

cwithagen@feweb.vu.nl

1 Department of Economics, Birmingham University, Birmingham, United Kingdom

2 IPAG Business School, 183 Bvd St Germain, 75006 Paris, France

3 Department of Spatial Economics Vrije Universiteit Amsterdam, Amsterdam, The Netherlands 
on government debt and stimuli, proposals for New Green Deals and other governmental interventions, and what lessons Covid-19 has for empirical research in this area.

Many of the issues that we present here are clearly still speculative. However, the points that we raise are based wherever possible on established results from the literature. In particular, as the pandemic is still ongoing, and since many of the articles that we cite are, as of now, currently unpublished and thus have not gone through the usual rigorous process of peer reviewing, we have decided to focus less on actual data but more on general lessons and implications.

Making suggestions for a post-pandemic research agenda in environmental economics based on the lessons learned from the pandemic that we are still in the midst of, is necessarily highly subjective. There are many important issues that we will not touch upon, or if then only briefly. Fortunately, these issues are covered to some degree by other contributions. These topics include, among others, potential changes in behavioural responses such as social norms (van Bergeijk 2020; Howarth et al. 2020; Quaas et al. 2020), issues related to health economics and disease transmission (Newbold et al. 2020; Brock and Xepapadeas 2020; Albers et al. 2020), food safety and availability (Kecinski et al. 2020), impacts on the Market Stability Reserve (Gerlagh et al. 2020), animal disease and wildlife meat trade (Aguirre et al. 2020), the valuation of lives and the economic costs and environmental benefits of the lockdowns, stock price reactions (Ramelli and Wagner 2020) and linkages to mobility patterns (Sirkeci and Yucesahin 2020).

This article is organized as follows. Section 2 discusses the lessons from the Covid-19 crisis for globalization and cooperation in the light of environmental concerns. Section 3 investigates the impact of Covid-19 on the green transition via the lockdown's impact on carbon emissions, on the proposed New Green Deal, on the role of government debt and on the future pricing of carbon emissions. Sect. 4 discusses some further lessons that we draw from the Covid-19 crisis so far, in particular implementability and timing of policies. In Sect. 5 we study the empirical literature and draw lessons on its applicability and potential pitfalls. Finally, Sect. 6 concludes.

\section{Globalization and Cooperation}

The World Trade Organization (WTO) issued its annual Trade Outlook in April 2020, not long after the Covid-19 virus outbreak. The Director-General Azevêdo said, the "numbers are ugly" (WTO 2020). In its updated World Economic Outlook (IMF 2020), the IMF estimates that world GDP may decrease by $4.9 \%$ in 2020 . Alarming figures on international trade are also found by Barry (2020). It is estimated that the pandemic will lead to a reduction in world trade of between 13 and $32 \%$, a decline that surpasses the one caused by the global financial crisis of 2008-09. Moreover, "[t]rade is likely to fall more steeply in sectors characterized by complex value chain linkages, particularly in electronics and automotive products. Services trade will also be highly impacted due to the imposition of transport and travel restrictions and the closure of many retail and hospitality establishments" (WTO 2020). The WTO also argues that a rebound may occur if the expectations of businesses, as well as consumers, are that the shock is only temporary. To achieve a, so-called, V shape recovery, and against a backdrop of an increasingly fraught trade war between the US and China, it is important that post-pandemic governments do not revert to further rounds of protectionist policies but to the creation of an environment that enhances the prospects for beneficial trade. 
In the political arena, as well as among economists, there is considerable discussion on how desirable it is to use the present Covid-19 crisis to tackle and reduce the negative effects of globalization. Globalization has two intertwined aspects that both revolve around a central idea, namely international cooperation. The two aspects are opening up economies for trade and collaboration in the fight against global externalities, in particular climate change, but also to combat such threats as nuclear proliferation and diseases. The second aspect is relevant for our profession of environmental economics. The first aspect is also important because it is related to the potential worsening of environmental conditions due to emissions from the increased transportation of goods and the potential relocation of pollution intensive firms to countries with less stringent environmental regulations.

We begin with a brief history of globalization to put these issues into perspective. Then we address the question whether the Covid-19 crisis has had a short-term effect on globalization and what we might expect the effect to be in the long-run. We then ask what are the consequences for research in environmental economics: First, regarding increased or decreased trade in goods and services and greater or less mobility of people; and second, what is the effect of Covid-19 on attempts to undertake multilateral action to combat threats such as nuclear proliferation, disease and climate change. So, the first question is whether the Covid-19 crisis is likely to lead to a potentially long-lasting period of deglobalization, and how, or whether, that should change the research agenda of environmental economists. The next question is whether, if Covid-19 does lead to a reversal of the upward recent positive trend in globalization, will this make countries more or, to the contrary, less resilient both economically and in terms of being able to deal with future shocks. The argument in favor of increased resilience is that supply chains become shorter and certain goods, for example, PPE and medicine, are then more likely to be locally produced. The counter-argument is that prices are likely to be higher and that having a geographically diverse supply chain actually improves an economy's ability to cope with future shocks especially those that tend to be geographically specific such as natural disasters.

\subsection{A Brief History of Globalization}

Globalization has a long history, starting with the Silk Roads (first century B.C.-fifth century A.D. and in centuries 13-14). ${ }^{1}$ The first Silk Road marked the introduction of trade over long distances, when Chinese products first reached Rome. An essential feature was the protection of these trade routes by strong world powers. After the first Silk Road came the Spice Routes (7th-15th), thanks to Islamic tradesmen, who went as far as Indonesia. According to Vanham (2019) global trade (with large volumes of trade) truly started in the so-called age of "discovery" by Europeans (in the 15th-18th century) when trade become truly global. Still, this could not rightly be called globalization because trade was mainly between European empires and their colonies. The first true wave of globalization took place in the first industrial revolution in the UK, when Britain made products (e.g. iron and textiles) for which there was global demand. In addition, massive investments were made in different locations around the world to facilitate trade (e.g. the Suez Canal, and a massive expansion of the railways). Vanham (2019) argues that the hegemony of the USA after the second World War led to the second wave of globalization. The world then arrived at what is called the third wave of globalization after the fall of the Iron Curtain and the

${ }^{1}$ This section relies heavily on Vanham (2019). 
creation of the WTO. During this period world exports rose to $25 \%$ of world GDP. During this time a majority of global population has benefited from this: "more people than ever before belong to the global middle class, and hundreds of millions achieved that status by participating in the global economy" (Vanham 2019).

The current period has been referred to as globalization 4.0, a world dominated by China and the US. The main features are e-commerce and digital services. However, the negative aspects of globalization are becoming increasingly recognized, of which, deforestation and pollution are two of the main environmental concerns. ${ }^{2}$ In addition, there is now greater awareness of rising inequalities both across and within countries and a perception that mass immigration can have a negative impact on native populations. One may also ask whether immigration has a positive or negative effect overall, once we take into account both the 'sending' and the 'receiving' countries. We have also entered a period where we are once again seeing trade wars and increased protectionism, driven, in part, by the US withdrawing more and more from the international arena. Such geo-political posturing may pose a problem for globalization in view of the fact that the previous waves prevailed by virtue of the support given to them by the existing world power at the time.

\subsection{Rethinking Globalization Versus-Deglobalization}

Rethinking globalization takes place on many fora nowadays. Although normally economists do not agree, there is much agreement now. Almost all economists acknowledge that there are both positive and negative effects of globalization, but also think that the present era is the right moment to take proper action. One exception is ( Barry 2020) who sees Covid-19 as the third major blow to globalization after the 2008 crisis and the US-China trade war and who concludes: "Wave goodbye to the greatest era of globalization- and worry about what is going to take place".

There are also suggestions that the current approach to international trade and increasing urbanization, coupled with significant urban sprawl, has increased the chances of a communicable disease such as Covid-19 arriving on the world scene (Gruszczynski 2020). Furthermore, there are estimates that climate change may increase the probability that more of these communicable diseases will spread around the planet (Shope 1991). If the probability of a communicable disease increases with climate change, then this is an indirect effect that needs to be taken into account. This can be modeled via a stochastic process, where an increase in carbon emissions drives climate change, which then increases the probability of infectious diseases. This, in turn, has an additional impact on development. Future research along these lines would thus combine the optimal control of a communicable disease (Boucekkine et al. 2013), with integrated assessment models (such as Nordhaus 2014). An additional possibility is to model infectious diseases as a random, endogenous shock. One could model this in the form of an endogenous discount rate (e.g. Schumacher 2009), or via a Lévy process (Poisson, Wiener) that affects capital or population (Steger 2005).

In a discussion of the dangers of deglobalization ${ }^{3}$ the participants, including Dani Rodrik, are generally not in favor of erecting barriers to trade as a remedy in this crisis

\footnotetext{
2 Illegal logging in the Brazilian Amazon has accelerated during the covid-19 crisis with accusations that officials are using the pandemic as "as a smoke screen, a distraction" that allows the deforestation to take place (Gardiner 2020).

3 See https://www.project-syndicate.org/bigpicture/deglobalization-s-dangers?barrier=accesspaylog.
} 
and argue that it would cause a serious welfare loss that would particularly hit the developing world. At the same time, all participants in the discussion emphasize the necessity for cooperation and illustrate this by pointing to, among other things, climate change and sustainability. In an interview with AFP Gopinath argues that "The system is not perfect Going backwards is not a good strategy for growth and not a good strategy for alleviating poverty around the world". Her predecessor at IMF Maurice Obstfeld (on VOA news) argues that the crisis will not necessarily hamper globalization, because firms may want to reduce risks of local crises by spreading their activities more evenly over the globe. ${ }^{4}$ However, there is also broad agreement that it seems inevitable that countries will need to create redundancy and resilience in some strategic sectors, particularly the health sector.

One of the main drawbacks associated with globalization, and the increasing interconnectedness of economies, is the increase in certain inequalities that have resulted from the opening up of countries to trade, capital flows and the free movement of labor. We go briefly into these issues because they are relevant for our field as well.

A characteristic of globalization is the growing interdependence between economies. For example, firms are able to sell their final products in many markets, with these final products also consisting of parts and intermediate inputs that may have been produced in other countries and sourced from many different sectors. In a world where there are no great shocks or sudden policy changes, the increased interconnectedness poses no problems. However, the world is not free from such events. Referring to the Covid-19 crisis, EU president Von der Leyen said in her address to the European Parliament of April 16 2020: "Investing in large scale renovation, renewables, clean transport, sustainable food and nature restoration will be even more important than before. This is not only good for our economies, it is not only good for our environment but it reduces dependency by shortening and diversifying supply chains". Similarly, the French president, Emmanuel Macron, has argued for a strengthening of French and European "economic sovereignty" by investing at home in the high tech and medical sectors. ${ }^{5}$

In a paper on rethinking globalized supply chains, Shih (2020) mentions a number of threats to globalization and supply chains including China's export quotas for rare earth elements in 2010, the 2011 tsunami in Japan, and the current US-China trade war. The question arises as to what the effect of the COVID-19 crisis will be in this respect. As suggested by the title of his contribution, Shih recommends rethinking supply chains. In particular, firms may consider embracing a greater degree of regionalization where suppliers to a firm are located in the same geographical region. There may also be more attention given to the development of, so-called, second sources of additional safety stocks. He also advocates rethinking the scale of production as well as the mix of products produced. A first quantitative study of the potential disruption due to the coronavirus is performed by Sforza and Steininger (2020) who study a large model with 44 countries and 56 sectors and shows that the Covid-19 shock implies a drastic reduction of income in all countries and in all sectors. Global linkages play a crucial role here. Müller-Fürstenberger and Schumacher (2017) point to another issue, namely the consequences of capital mobility. Although these publications do not specifically address environmental issues there are obvious lessons to learn for environmental economists. The reduction in income and production, and the possible reallocation of production as a consequence of deglobalization, will have significant

\footnotetext{
4 See https://menafn.com/1100380753/COVID-crisis-exacerbates-globalization-worries-IMF-economist.

5 https://www.ft.com/content/3ea8d790-7fd1-11ea-8fdb-7ec06edeef84.
} 
environmental effects at a global scale that are potentially positive and negative. Hence, an important research question is how to model and calculate these effects.

We also mention Calmette (2020) who argues that the Covid-19 epidemic should make us reconsider the principles of globalization in connection with supply chains. She points at the fact that globalization has been taking place in a world with global monopolies and without enough regulation leading to the undermining of vital sectors such as the health sector. She mentions that large numbers of medicines, such as penicillin and paracetamol, are now only produced in one or two countries.

Returning to globalization induced inequality. Increased international trade necessarily leads to winners and losers, not only across the countries participating in trade, but also within countries. Piketty's publications have made this perfectly clear. Piketty has also put forward : "Why didn't democracy reduce inequality? Well, in my view probably because you have multi-dimensional inequality structures, in particular globalization and migration on one hand, and educational expansion on the other hand. They have created new multidimensional conflicts about inequality." In addition, it is well-known that the poor suffer more from pollution which implies increasing environmental inequality (Lipfert 2004). The similarity between the losers from globalization and the likely losers from Covid-19 and those that will be most negatively impacted by climate change is that those most affected are likely to be the poor and vulnerable (Wu et al. 2020). In both cases, international cooperation is needed but in the case of climate change, appears further away than ever.

\subsection{A Research Agenda for Environmental Economics}

There are lessons to learn from Covid-19 for environmental economists, some of which have been alluded to above. The drop in income and production and the possible widespread relocation of production will have significant environmental effects. Hence, an important research question is how to model and calculate these effects. What do we have to say as environmental economists?

Economists have been aware of these potential environmental problems associated with trade. The well-known book by Copeland and Taylor (2003) on trade and the environment gives a nice account of the worries that have existed since the early 1990s. The key questions they address are: (1) How does the increase in economic activity induced by international trade affect the environment; and (2) How does environmental policy affect a nation's trade pattern? They discuss the pollution haven versus the factor endowment hypothesis. Since then, numerous studies have investigated these issues. As usual in economics, the answer is that opening up to trade in the absence of externalities tends to be beneficial, but that the 'right' economic policy is required to get positive welfare gains in the case of externalities. If the externalities are purely local then the country experiencing the externalities can remedy it on its own. If the externalities are (partly) global, then coordinated policies are required.

However, to account for the effects of Covid-19 we need models where the interconnectedness of production chains is prominently present. Moreover, the current Covid-19 crisis is also characterized by the reduced mobility of people, with consequences for the tourism and transportation sectors. Fewer tourists may lead to less damage to global biodiversity, but it might also be the case that less eco-tourism will mean that it is no longer "profitable"

${ }^{6}$ https://www.rug.nl/feb/blog/thomas-piketty-on-inequality-and-globalisation-17-07-2018. 
to continue to protect previously protected areas that are important for biodiversity. One clear benefit from less tourism is that there will be fewer $\mathrm{CO} 2$ emissions as a result of reduced air travel. Likewise, reductions in trade means less road, ship and air travel is needed for the transportation of goods and services. A crucial question is whether these specific effects will be long-lasting, or only temporary. A related issue is the huge subsidies that go to the aviation sector. Should these subsidies be coupled with greening the business and, as France is demanding from AirFrance/KLM, that domestic flights are reduced in favor of fast trains? Research is badly needed to estimate the costs and benefits of such a policy. Relatedly, shortened supply chains and reduced trade may also reduce the need for face to face meetings between affiliated companies and arms-length suppliers. This reduced travel may be exacerbated by the acceleration of new video conferencing that, now learned by millions, may permanently reduce the need for business travel.

Based on what we have seen, there is good reason to believe that in spite of isolationism emerging here and there, the gains from trade will be sufficiently high to keep that part of globalization intact, but that too greater a degree of interdependence will be prevented by building more resilient supply chains and introducing measures against too damaging monopolistic behavior. On the second pillar of globalization, collaboration to fight global externalities such as climate change, we are less optimistic. For example, with an eye to the green paradox, low oil prices are not necessarily desirable if we are to encourage greater renewable energy adoption although the United States' plea for higher oil prices, in order to make US shale oil competitive (again), is not reassuring either.

The same holds for the fact that some countries are not willing to commit to $\mathrm{CO} 2$ reductions. It is also to be feared that the financial crises will prevent many governments from imposing an appropriate level of carbon taxes or to take other effective measures. In addition, if a uniform carbon tax were to be implemented, some developing countries would need to be compensated for potential losses. The present tendency exacerbated by the upcoming economic crisis will be a potentially serious obstacle to overcome. It can now only be hoped that the EU and other blocks keep their promise to considerably reduce $\mathrm{CO} 2$ in the future.

Another reason for not being too optimistic is that a system of border carbon adjustment, that would remedy the absence of international agreements, encounters serious difficulties as clearly demonstrated by Cosbey et al. (2019) and Zachmann et al. (2020). For the present purpose of suggesting a future research agenda, we cannot but support the conclusions by Cosbey et al. (2019) that "important research gaps remain regarding the many of the practical and legal issues associated with the border carbon tax". Another threat, in terms of efficiency as well as global equity, is the possibility that individual countries (or blocks) may concentrate on adaptation instead of mitigation, if there is not enough support for a global agreement. Also here lies an important question for the environmental economist. When does this fear become real?

What makes the picture a little less gloomy is (perhaps even literally) that Covid-19 has given several countries clearer skies, as demonstrated by Cole et al. (2020a), Isaifan (2020) and Teale (2020). Reduced CO2 emissions are not directly responsible for this amelioration, but it is linked to reduced use of fossil fuels, so that an indirect link with climate change exists. People have now come to appreciate less exposure to pollution and the authorities may need to rethink the use of coal and other fossils to generate energy if the public begin to demand cleaner skies moving forward. Reduced traffic in cities is also a major benefit in terms of reducing pollution in NO2 and other local pollutants. Hepburn et al. (2020) consider the possible positive and negative effects of Covid-19 on climate change and tend to be very optimistic. They argue along several lines. In the short-run 
they argue that momentum in favor of tackling climate change will diminish as economies start up again. However, the crisis has also shown that it is possible for governments can take measures that have a great impact that also have the support of the people. This is important: The people are the ones who experience the benefits from clean air and the disappearance of congestion. Moreover, they realize that they, as individuals, are vulnerable and therefore not "omnipotent". The authors then conduct a survey among policy makers to see what future measures can both benefit the economy and the climate. Such measures include clean R\&D investment and investments in ecosystem resilience which they argue justifies their optimism.

However, in many regions, especially the very poor ones, there is not only an inherent lack of finance to implement a green transition, but there are also more urgent problems such as malnutrition or the wish of countries to first develop out of poverty traps. Someone who is more concerned with imminent survival is understandably less concerned with what happens in the more distant future (Schumacher 2009). While the climate negotiators initially understood this and split the world into Annex 1 and Annex 2 countries, today's climate negotiators have moved away from this approach to one akin to a non-cooperative approach and argue that all countries have a responsibility but that it is up to each country to decide about its desired efforts (the so-called NAMAs). However, it is well-known that the poor countries that bare the least responsibility for climate change are also those that will be hit the hardest (Mendelsohn et al. 2006), but that also require finances to help them achieve a transition towards a sustainable economy. This needs a degree of cooperation that the countries in the world appear reluctant to provide. For example, in the Covid- 19 crisis, we have seen that the poor have been hit the hardest (Wu et al. 2020). Furthermore, international cooperation, at various times during the Covid-19 crisis, broke down to a significant degree, not least over the supply of PPE equipment for healthcare workers.

One important question then, is whether this reduction in cooperation, and also the apparent move away from a path of greater globalization, harms both developing countries in their economic growth and also their environmental development. For example, how does the Covid-19 pandemic impact the passage of green technology transfer from rich to poor countries? Any energy infrastructure that developing countries build now will stay in place for several decades. Thus, an important research question is whether and how this crisis can be used to increase international cooperation between rich and poor countries on topics such as adaptation strategies, green energy transfers, and international carbon pricing.

\section{The Green Transition}

Any pandemic that leads to a lockdown, such as in the case of the 2020 Covid-19 pandemic, naturally gives rise to questions about what this means for economic growth, and by extension, and of primary interest for this paper, the environment. We are, at the time of writing, still unsure as to how long the recovery from Covid-19 will take. The question is whether there are lessons from Covid-19 that provide us with a blueprint or way forward that will make the green transition, meaning a transition to a sustainable, low carbon economy, easier compared with the situation prior to the current crisis. 


\subsection{Lessons from Lockdown for Carbon Emissions}

Perhaps one of the biggest lessons we have learnt from the comprehensive lockdown and the ceasing of vast swathes of economic activity is just how small the reduction of greenhouse gases has been. The International Energy Agency expects a drop of 6\% in the world carbon emissions in $2020 .^{7}$ This is equivalent to the annual carbon budget of countries such as India. However, while this drop is unprecedented as such, in order to keep climate change to $1.5^{\circ} \mathrm{C}$ of warming by the end of the century, we would need at least an equivalent drop in carbon emissions every year from now on until 2050 (UNEP 2019). Despite this need for further reductions, the current evidence suggests that pollution levels bounce back quickly once economies reopen for business as usual. Gardiner (2020) in the National Geographic explains "why covid-19 will end up harming the environment" arguing that post-pandemic carbon emissions may "surge past pre-pandemic levels" as the world engages in a "dirty recovery". While a lack of herd immunity or a working vaccine implies that some sectors, such as aviation and the hospitality industry, will see a lower demand for some time, many other sectors are quickly restarting after a lockdown hiatus. The overall effect is still unknown and depends on the shape of the recovery. A global depression with high levels of unemployment and diminished investment may suppress emissions for some time to come.

The Covid-19 crisis has put into stark relief that even with huge sacrifices in terms of how people go about their daily lives, this has not brought us much closer to the emission reduction levels needed to meet the Paris agreement's goal of limiting warming to $1.5^{\circ} \mathrm{C}$. From this we can draw some implications for the degrowth debate. This literature (see e.g. Weiss and Cattaneo 2017) starts with the premise that endless growth on a finite planet is impossible. As a consequence, we need to find ways to either stop our desires for growth and to catch up with the Joneses, or we need to find ways to decouple our growth from nature's constraints. The question is whether this can happen through policy and social change before this, or the next, crisis induces forced degrowth (Research \& Degrowth 2010), or whether it is only the actualization of a crisis that is enough to generates degrowth (Sorman et al. 2013). The recovery from the 2008 financial crisis took around six years. Given the current impacts of the Covid-19 crisis, and given the uncertainty about how long this situation will continue, we are as of now, still unsure how long the economy will require to recover. What is clear, however, is that the emission reductions from locking down an economy are by no means enough to sufficiently limit climate change. Instead, what we need in the longer run is a decoupling of emissions from the economy.

\subsection{Degrowth Refers to Reduced Emissions or to Lower GDP?}

Most government policies so far during the pandemic crisis have been directed towards reducing the extent of an economic recession. ${ }^{8}$ Furthermore, while consumption expenditure significantly decreased during the various lockdowns around the world, there are signs that spending is once again picking up. ${ }^{9}$ The Covid-19 crisis has thus, despite initial

\footnotetext{
7 https://www.bbc.com/news/amp/science-environment-52485712.

8 https://www.imf.org/en/Topics/imf-and-covid19/Policy-Responses-to-COVID-19.

9 https://www.mckinsey.com/business-functions/marketing-and-sales/our-insights/a-global-view-of-howconsumer-behavior-is-changing-amid-covid-19.
} 
beliefs, not led to a widespread social momentum for individuals and families to change their pre-crisis consumption habits. This suggests that, as of now, there is little support for the hypothesis that humankind's demand for further economic growth will diminish anytime soon.

However, while a quick return to old habits after the end of lockdowns is evidence that points towards a preference for current lifestyles, coupled with current consumption levels, there are some that are pushing for social change (Holmberg and Alvinius 2020). For example, the lockdowns have required a significant number of employees to work from home. This led to improvements in local air quality as a result of less road traffic (Cole et al. 2020a), but reduced commuting time also has implications for worker health and family life, some of which has been positive but also a lot that has been negative (Dockery and Bawa 2020). ${ }^{10}$ An important question is who wants this lifestyle? Do employees want to work from home, or do companies prefer them in the office ${ }^{11}$ Do consumers want to reduce their consumption spending, despite advertising driving them onto ever and ever higher consumption levels? This suggests a need for an even larger cultural, social and political change in order to reform institutions and cultural practises if we are to speed up a green transition (Kallis 2011; Hepburn et al. 2020). While the movement Fridays for Future ${ }^{12}$ (Kühne 2019) is an example that suggests there is the possibility to change attitudes, there is still a large gap between attitudes and actual social change. Important research questions should address which sectors would become (partly) obsolete if there was to be a change in lifestyle towards one that is less travel-based or more sustainable? What would be the socioeconomics costs of such a transition? How could one design an appropriate transition that would minimize the costs? How can we get positive pro-environmental attitudes to turn into actual social change?

\subsection{The New Green Deal}

So far, the stimulus plans of developed countries have been large in scope and cost but have mainly been aimed at shoring up local economies and have only very limited global ambition when it comes to issues such as climate change or support for the international community. It obviously does make some sense to use Keynesian policies to counter the drop in demand induced by a lockdown. However, there seems to be a growing concern that trying to simply increase consumption as part of any stimulus plan is likely to worsen existing environmental problems. The relationship between GDP and emissions is as strong as ever so any increase in growth will result in increased emissions. The emission gap to minimize warming to $1.5^{\circ} \mathrm{C}$ will not be closed without stimulus packages that are more specifically targeted towards the green transition. Two thirds of the world citizens feel that the climate crisis is as serious as the Covid-19 crisis, which shows that there is strong public support

\footnotetext{
${ }^{10}$ For example, due to Covid-19, public transport has seen a significant reduction all over Europe, and demand for cars has increased.

11 One recent article (Papanikolaou and Schmidt 2020) finds that companies that are more flexible in terms of remote work have fared better during the Covid-19 crisis (in terms of employment, revenue growth, stock market performance, default) than companies that cannot easily make their employees work from home.

12 Fridays for Future is a recent international social movement that relies, among others, on student protests to increase social awareness and policy directed towards climate change, see https://fridaysforfuture.org/.
} 
for integrating environmental objectives into any post-pandemic recovery strategy. ${ }^{13}$ Some countries are thus in the process of directing their post-pandemic stimulus programme towards a green transition and focusing their spending more strongly on investments with lasting value. These proposed stimulus packages have been dubbed the New Green Deal (Elkerbout et al. 2020). ${ }^{14}$

While there are already budget proposals for the New Green Deal stimulus packages (at least at the EU level), an important question is whether it makes sense to focus these stimuli on green investments. A big question is whether the money spent on green investments provides enough widespread economic benefits to act as a general Keynesian stimulus while at the same time helping to further decouple economic growth from the environment. With reference to the EU Green Deal, there are a number of arguments suggesting that, indeed, green investment will lead to better growth returns that brown investments. Aberdeen Standard ${ }^{15}$ states that "[a] growing body of evidence suggests that fiscal stimulus directed towards clean-energy products will have higher economic and job multipliers than other spending actions". They go on to say that "[t]here are already signs that governments in European and Asian countries are seizing the initiative by strengthening their climate goals and policies." Examples of green investment include tree planting, low carbon transport infrastructure, building retrofits (insulation or solar panels). These have short-term and longer-term benefits for an economy. Other examples are the greening of cities with the aim of achieving carbon neutrality coupled with investments in new green technologies; that bailouts should include environmental targets attached so that airlines or cars become cleaner as a condition of financial help; and greening the electricity grid.

While the benefits of these investments have been well elaborated, there is still the question of whether there are important costs that arise simply because of sudden changes in government investment strategies. One question is whether investments in so-called green sectors disrupts existing supply chains. Very often, even the companies themselves are not aware of all their supply chains, and thus it would be useful to pursue research that helps to determine whether and how disruptive green stimuli might be to existing sources of intermediate goods. There is also a danger associated with brown investments (e.g. gas or coal fired power stations) that such investments will turn out to be stranded assets as green technologies become increasingly competitive and no longer need state subsidies to survive. The currently low oil prices also make it harder for fossil fuel free technologies to compete on the basis of leveraged costs, which could require further government interventions.

Such interventions are likely to significantly change the competitiveness of certain industries or sectors, both horizontally and vertically, but also internationally. Research needs to address this issue in order to understand whether there is a race-to-the bottom, or whether this will lead to a significant flight of firms from currently dirty industries to countries with low levels of regulation and thus create new pollution havens. The likely impacts on regional competition would thus benefit from a significant degree of cross governmental

\footnotetext{
13 See e.g. https://www.ipsos.com/en/two-thirds-citizens-around-world-agree-climate-change-serious-crisi s-coronavirus.

14 For a complementary discussion that investigates how the green stimuli should look like, see Barbier (2020). See Stern et al. 2020 who outline plans for an investment strategy for a strong and sustainable Covid-19 recovery for the UK and Allan et al, (2020) for proposals for a "net-zero emissions economic recovery from Covid-19" arguing for a new National Investment Bank with a focus on green financial instruments.

15 https://www.aberdeenstandard.com/en-us/us/investor/insights-thinking-aloud/article-page/covid19-andthe-environment--a-ray-of-light.
} 
cooperation. Research would need to address the costs and benefits of these changes to sectoral and international competition in order to advise policy on the best means for cooperation.

Empirically, there are several important challenges. For example, measuring the benefits of green stimulus will be difficult. Firstly, it is often not straight forward to distinguish between green and brown companies. Secondly, the returns to natural capital have characteristics of public goods where the benefits are outside of formal markets. This means there may need to be improvements in how natural capital is included in national accounts. The new interim report of The Dasgupta Review (Treasury 2020) provides novel insights into how nature should be valued and how this valuation should be integrated in our growth assessments.

While measuring the impact of any green stimulus program is important, we also need to consider an alternative reaction of governments to the pandemic. A natural response to Covid-19, that has already cost millions of jobs, is to roll back environmental regulations so that traditional dirty sectors are not only able to survive, but in some cases, expand production and employment. Hence, far from a green transition it is possible that in the short-term we may even have what could be called a brown transition. This is no more clearly demonstrated than by the actions of the Trump administration to roll back a series of environmental regulations prior to the start of the Covid-19 crisis, a trend which has continued, and if anything, increased during the crisis. For example, the current lockdown period has seen fuel efficiency standards reduced for new cars and a freeze placed on new soot air pollution. Reporting rules for polluters have also been reduced. The argument that the United States (US) government puts forward is that the changes are merely correcting for regulation over-reach and that this is simply a simplification of regulations and a time to fix problems with existing regulations. ${ }^{16}$ Without a strong research-based analysis, something that the US government has not provided, it is difficult to know whether these decisions are warranted or not.

The Brookings community lists 24 notable changes to EPA regulations that are already in effect, repealed or in rulemaking. Eight of these have been implemented in 2020 including Mercury and air toxic standards, suspension of EPA enforcement and the changes to the Clean Air Act. What is needed is research that examines each of the different policy rollbacks to estimate the environmental costs in terms of health and damage to the broader economy and how these compare with any possible environmental benefits that may arise from reduced costs or increased global competitiveness. The first study to examine the impact of the the EPA rollback on Covid-19 related deaths and cases is Persico and Johnson (2020) who show that policy-induced increaes in pollution are associted with a $38.8 \%$ increase in cases and a $19.1 \%$ increase in deaths from Covid-19. Gardiner (2020) quotes Lukas Ross of the Friends of the Earth who argues that "[T]here's a serious risk that polluters could emerge from the crisis bolder and potentially more profitable than ever".

This, then, leaves questions about the future of the green transition. In particular, we need research to understand how different kinds of crises lead to changes in the composition of government funding that in turn affects funding for the green transition. As an example, the European Union (EU) is attempting to use the Covid-19 crisis to speed up the green transition via its New Green Deal, whereas the US cuts funding for projects directed towards the green transition and invests proportionately more in traditional, dirty energy

\footnotetext{
${ }^{16}$ Details of the regulatory roll backs can be found here: https://www.brookings.edu/interactives/trackingderegulation-in-the-trump-era/.
} 
resources. This move away from a green transition is particularly profound in the US, and goes along with a shift from policy-based research to a reliance on beliefs that are influenced by different lobby groups (Samet et al. 2020). For example, due to the low price, many oil producing and exporting countries are finding it hard to balance their government budgets. This may lead to collusion or changes in the structures on the oil and gas markets which again has an impact on their lobbying potential. Research is needed to address whether there is an imbalance in the influence of some lobby groups when it comes to policy making, and it would be useful to study more deeply how institutions can be designed to make lobbying efficient (in the sense of reducing dead-weight losses).

\subsection{Government-Financed Stimuli}

Expected global economic growth in 2020 would be considerably lower if governments around the world had not increased their debt levels substantially as a means of financing supportive social security measures. As a result, in advanced economies, general government borrowing minus lending has increased to $10.6 \%$ of GDP. According to the Spring 2020 version of the EU Economic Forecast, the aggregate government deficit of the EU is expected to increase from 0.6 of GDP in 2019 to $8.5 \%$ in 2020, with similar numbers for the rest of the world.

Increasing debt levels will have significant implications for the ability of governments to debt-finance green $\mathrm{R} \& \mathrm{D}$ and the green transition more broadly. As previously discussed, there are already numerous examples suggesting that governments, to enable them to finance a country-wide stimulus, have started to roll back environmental regulations, or have halted spending on a green transition (Schumacher et al. 2020). During, or in the aftermath of crises, even leading policy makers tend to slow down previously ambitious environmental policy targets (Burns et al. 2020).

Money that is borrowed, at some point, needs to be paid back. Indeed, it may also be possible that those borrowing the money will not be the ones paying it back. The larger macroeconomic debate is whether stimulus of any colour, green or brown, is inflationary or whether the crisis will cause a period of deflationary pressure when governments are able to continue with the process of monetarising debt with little consequence. One would imagine that the fiscal multiplier, with interest rates at historic lows, is positive such that additional spending will lead to additional growth. The question is which kind of technologies are favoured by these low interest rates, traditional, dirty technologies, or green and clean ones? Many green technologies are still considered to be emerging, which means they may lack the infrastructure or the market depths for large scale, quick deployment. However, without sufficient government funding, these technologies may not make it on the market. A potentially useful avenue for future research would be to examine the impact of debt and post-pandemic recovery policies on the development and deployment of environmental technologies.

A further consequence of the stimulus spending, especially in developing countries, is that it has exacerbated existing inequalities that may worsen further as economies begin to recover unless the spending is carefully targeted at vulnerable groups (De Beer 2012). While the additional debt taken on to deal with the Covid-19 crisis has been used in countries with a social security system to, among other things, minimize the increase in unemployment, countries with a more market-based approach such as the US have seen a surge in unemployment to an all-time high of $14.7 \%$ in April 2020. This again raises questions about the distributional aspects of a New Green Deal stimulus policy, such as the one 
proposed by the EU. An analysis of how the New Green Deal will impact employment and various aspects of the distribution of these new jobs between skilled and unskilled, high wage and low wage and clean or dirty, would be useful. Overall, we argue that this requires strategic rather than reactive aid packages. Thus, research has to address several jointly determined issues: (1) the problem of how governments can direct stimuli towards supporting the green transition; and (2) the problem of how to do this not only in an efficient but also equitable way.

In addition, higher debt levels due to crises (like the 2007 financial crisis or the 2020 Covid-19 crisis) may force governments to cut environmental subsidies for two reasons. First, as government revenues shrink, it implies an overall smaller budget; and, second, there is a need to increase social security expenditures to support counter-cyclical policies. This has both important implications for a green transition and for distributional aspects in general. Subsidies that impact a green transition can be cut on two fronts: direct subsidies, which tend to come in the form of price subsidies and thus change relative prices; or indirect subsidies, that come in the form of R\&D support and thereby change innovation and deployment of potentially new technologies. Furthermore, subsidies can be cut to different degrees when they are directed towards renewable resources or towards non-renewables. As a result, a change in government subsidies is likely to change the direction of technical change, and consequently the profitability of both green and traditional producers. While there are many articles that address the optimal direction of technical change (Greaker et al. 2018), we still have very little knowledge about how much money should be optimally spent on changing relative prices or on investing in indirect measures such as R\&D investments. Furthermore, we lack a good understanding of how changes in the composition of government subsidies or investments affect the green transition, or what would be an optimal response of governments during or after a crisis. A crisis like the Covid-19 has significant potential to change the way government budgets are used (for example, the EU New Green Deal), but without a deep assessment of how these changes impact the economy we are never sure whether or not this is necessarily a welfare-improving policy.

There is also a more international dimension to this debt problem. Many poor countries have had to substantially increase their levels of debt, thus requiring them to also reduce subsidies originally intended for the green transition (IEA 2020). However, at the same time, any investments in infrastructure that are done now in developing countries will remain in place for many decades to come (e.g. investment in coal-fired power stations). This will mean that a series of crises, such as the 2007 financial crisis closely followed by the Covid-19 crisis, may significantly slow down green development, or may even tilt their choices towards the established, sometimes still cheaper, traditional but dirty technologies. Future research on the impact of debt forgiveness and green investment would be useful, and more specifically, whether debt forgiveness conditional on requirements tied to investments in green infrastructure is welfare improving.

\subsection{Pricing the Carbon Externality}

An obvious option for governments who need to fill a gap in the budget bought on by a crisis the size of Covid-19 is to increase taxes. Such an argument is made by Burke et al. (2020) who argue that carbon pricing with a reduction in fuel subsidies should be part of any economic recovery plan. Although a seemingly simple option, once again, we need to understand the distributional aspects of any tax rise as these will play a significant role in garnering public support for any tax raising policy. Research needs to clearly assess when 
a tax is progressive, and when it is regressive. This distinction depends on the market, the substitutes available, and the tax itself (Sterner 2012). Thus, any increase in taxes may require an additional redistributive policy, which again needs a detailed assessment as this may further distort the market.

In terms of clear policy suggestions, post-crisis, a carbon tax remains the policy that appears to be the one that is most popular with economists although less so with the general public. As with all environmental taxes, how it is implemented will go a long way to determining its success. One solution that is likely to be popular with the public is to introduce a policy that aims to return some of the tax raised back to low income households. Given the rapidly falling price of renewables, from wind to solar, a relatively small carbon tax may be sufficient to turn a trickle of renewable investment into a flood. Predictions are that the gains from a carbon-pricing scheme would be considerable and that any competitive effect could be offset with a carbon border tax adjustment, although that has its own political hurdles to overcome as we have previously discussed. Here conclusions are still not definitive. Some suggest that a carbon border tax would be useful (Cosbey et al. (2019)), while others argue that it would not welfare improving (Zachmann et al. 2020). More research is thus necessary to complete the picture.

A recent article by Martin et al. (2020) takes the argument for a carbon tax a step further and proposes a strategy by which a government announces today that a carbon tax of around 56 Euros a tonne will be introduced at some point in the future (they suggest 2025). This is predicted to solve two distinct problems. First, it will boost future public finances that could retrospectively fund the current Covid-19 spending (although the amount raised will be impacted by policy induced technological change), and second, it will postpone any negative competition effect (from higher taxes) and therefore reduce the potential for carbon leakage which would result from firms relocating to less stringently regulated countries to avoid paying an immediately introduced carbon tax. Indeed, part of the argument for a Covid-19 carbon tax to be announced now but not imposed until a later date is that this implied threat of increased future costs may be enough to persuade firms and households to invest now in carbon saving technologies and behaviours. The pre-announcement also has the benefit of being costless to firms in the short-term so as to not financially impede a general recovery from the pandemic.

Martin et al. (2020) are aware that suggestions such as theirs require careful assessment. For example, the announcement of a delayed implementation carbon tax may lead to a green paradox effect, such that owners of non-renewable resources sell their polluting resources quickly and cheaply because they would become increasingly worthless later. Research needs to address this complication and help to understand whether this is an overall welfare-improving suggestion. Such a policy also needs to be considered in the context of current and future energy prices. Today's relatively low oil prices may make it politically easier to cut fuel subsidies that keep the price of gasoline low while at the same time making it simpler for a carbon tax to be introduced. A delayed implementation would also take off the immediate pressure as the fossil fuel sector is already undergoing substantial change making this policy more palatable for business leaders.

Economists tend to argue that one externality only requires one instrument. Hence the push for one carbon tax, or one cap-and-trade system. In reality there already exists a substantial number of regulations, subsidies, taxes and environmental standards. How do we know whether an additional tax on carbon will necessarily lead to a first best solution? This issue arises as we tend to build models based on the premise as to what ought to be, rather than start with what is. The reason why there are so many instruments already in use is because the political process leading to the implementation of policies requires trading 
off the interests of different competing groups. While economists tend to ignore this constraint, it is not so easy for politicians. It is, therefore, important to understand further how the various instruments that are at a politician's disposal fit together. Are they substitutes or complements? Are they necessarily welfare improving or is their combination harming other developments? When does the combination of the currently used instruments, or those proposed in the New Green Deals, lead us closer to an optimal outcome? It is likely that the Covid-19 crisis will favour one policy over another and the question of who are the likely winners or losers remains the subject of important future research.

\section{The Role of Uncertainty and Timing}

There are other aspects that deserve a separate look. Here we look at the role of uncertainty for policy making. In addition, we discuss the timing of policy interventions, and the related issue of implementability.

\subsection{The Role of Uncertainty}

As previously discussed, lockdowns across the world have led to a significant reduction in economic activity. The January 2020 version of the IMF World Economic Outlook predicted that the global economy would grow by $3.3 \%$ in 2020 . Instead, on the back of the Covid-19 pandemic, the April 2020 version of the IMF World Economic Outlook has updated its previous forecast and now expects that global real economic growth may turn out to be minus $3 \%$, with a potential U-shaped recovery of $5.8 \%$ growth in 2021 . This suggests a tendency to significantly underestimate the probability of extremes if one has little prior knowledge of the potential states of the world. This is also a recurrent theme in the climate change debate, where, for example, the IPCC report from 2007 concluded that $2{ }^{\circ} \mathrm{C}$ of warming would be a somewhat safe upper bound for climate change, whereas the latest reports suggest that even exceeding warming of $1.5^{\circ} \mathrm{C}$ would result in large and potentially catastrophic costs (IPCC 2018).

While it is well-known that the expected costs of low probability, high impact incidents (such as airplane crashes or nuclear plant disasters) tend to be overestimated (Barberis 2013), there is still significant uncertainty around those impacts that are not directly visible, or have not yet materialized, leading to an underestimation of these costs. Climate change is a good example of an event that is known about but the costs of which are not yet directly visible to the average person in a developed country. Other examples include the case for PTFE (Teflon), plastic pollution, noise pollution or potentially carcinogenic substances such as herbicides, fungicides, and pesticides. Faced with uncertainty, it is an open question as to why this uncertainty does not lead to an equally likely overestimation of these costs? Only learning about the impact seems to then tilt expectations towards a more balanced view of the expected costs (Bistline 2015). Hence, it is possible that the experience of both governments and the public of the Covid-19 pandemic may open their eyes to the potential costs from continued inaction over climate change. Hence, the experience of going through such a negative lifestyle shock may promote pro-climate behavioural change. It is, therefore, important to carefully study and be informed about the costs and benefits from climate change taking into account different degrees of uncertainty. This becomes even more important when we consider issues such as fat tails (Weitzman 2009). 
While there have been some contributions along these lines (Jensen and Traeger 2014), there are still many open questions.

A related issue is the ability of individuals, once a certain benchmark belief has been established, to lock-in of this belief (Jones and Sugden 2001). If new information arises, as in, for example, the case of climate change damage, then it is often difficult to convey to the general public or policy makers that they now have to revise their beliefs. This is very much visible when we look at what carbon price policy makers currently view as reasonable. Their opinion tends to be strongly driven by past carbon prices that are a legacy of the first generation of models such as the DICE model (Nordhaus 2014), and not so much by models that include many other aspects such as uncertainty or abrupt threshold damages (Dietz and Venmans 2019). Future research should therefore not only have to present baseline results, but also suggest more strongly how these would need to be adjusted if one were to take some more realistic generalizations into account, that include issues such as uncertainty, interdependent preferences and political constraints.

\subsection{Timing of Policy Interventions}

An important lesson from the Covid-19 crisis so far is that the timing of policy interventions is decisive. Countries such as Taiwan, that reacted quickly, have had, up to now, far fewer cases and deaths than countries that delayed their lockdowns. There were several countries, such as the US and the UK, that underestimated the potential impact of Covid19 and thus failed to respond quickly enough (based on the number of fatalities per capita). Here the question is whether the speed and magnitude of any government action is due to some general social attitude that then drives policy making, or whether this is a general attitude that extends to policy making in other domains, such as climate change or pollution. Future research could thus usefully address the question of what determines a country's responses to a crisis, and what determines early responses (such as in Taiwan).

Giovanniello and Perroni (2020) study the differences between social and private optimum in optimal timing of investment decisions under external effects. They show, for example, that positive external effects induce overly-cautious decisions, while negative externalities lead to the opposite effect. This result naturally has important implications for international cooperation. Models like these could then be extended to study coalition formation or the weakest link public good (Caparrós and Finus 2020).

Furthermore, while timing is important, the choice of the policies and the circumstances that lead to these choices are also crucial. For example, it was possible to impose country-wide lockdowns on the public because they were viewed as a necessity simply due to the fact that there was a huge uncertainty around the number of people that were infected. This shows that, when faced with uncertainty, it may be wise to err on the side of caution, although such caution may come at a significant perceived or real economic cost. While there is a literature on the precaution principle (Aldred 2012), we still lack a good understanding of many different aspects that flow into cost benefit analyses. For example, we have very limited knowledge of the actual shape of damage functions (Diaz and Moore 2017). While the IPCC shows that impacts on a variety of ecosystems are very severe already for a $2{ }^{\circ} \mathrm{C}$ warming (IPCC 2018), our integrated assessment modelling often suggests that we will face only small costs at that level (Tol 2009). It is thus an important urgency to understand where exactly this discrepancy comes from.

The UK was also a special case where the first objective of the government, based on what they said was sound scientific advice, was to go for herd immunity, until the moment 
it understood that this would not only lead to a very large number of deaths, but also that the constraints on the health system would lead to a cascade of additional deaths and complications. In environmental economics, these thresholds are seldom taken into account. There is a significant though highly abstract theoretical literature on the optimal control of thresholds (e.g. Mäler et al. 2003), but this still finds limited applicability in the policy debate and in the overall calculations of carbon prices.

The heterogenous response of countries and even regions within countries can provide valuable insights for a number of areas of environmental research particularly on the issues of implementability and timing. When it comes to policy suggestions, economists tend to focus on the first best. This first best is derived from theoretical models that rely on Occam's razor to pick out only the essential parts. Doing so allows economists to neglect the many smaller issues that may have a positive, but not crucial, effect. What economists, however, mostly neglect is the strategic interaction part of political economy. For example, in climate change economics, nearly all IAMs either only consider a global, benevolent policy maker, or look at a non-cooperative, region-based solutions, and how to implement the first best global solution despite a non-cooperative setting. This neglects the very important issue of implementability, which may require a solution that is neither first best, nor even second or third best. While we should obviously aim, at least in the long run, to implement the first best solution, it would be also important to understand whether approaches that are not first best, but implementable now, may be welfare-improving to policies (such as carbon prices) which may only be implementable with a long delay. This issue was discussed above. As the many rounds of international negotiations (the COP meetings) have shown, the agendas of politicians are shaped by many interest groups. While first-best should be the ultimate goal, the long delay in implementation of carbon pricing shows that any delays are extremely costly and ultimately require more and more stringent policy intervention, up to a point where individuals are not willing to pay the price any longer.

\section{Empirical Challenges}

In this section we turn to the empirical questions that environmental economists have so far addressed arising from the Covid-19 pandemic and what lessons we can learn. What we do know is that the pandemic has resulted in a large number of empirical Covid-19 related papers. These papers have been written despite three main challenges: (1) the pandemic is still ongoing; (2) data quality is questionable (due to data reporting that may be under-reporting the number of deaths and cases, and in some cases over-reporting the same numbers), and (3) that after the news broke of the new disease in Wuhan that could be spread from human to human there will always be some degree of anticipation effect in other populations. A fourth related challenge is that getting out papers quickly often comes at the cost of intensive peer review. This was demonstrated recently by the withdrawal of papers from the Lancet that promoted the use of hydroxychloroquine or chloroquine with or without a macrolide to treat Covid-19 (Mehra et al. 2020).

One of the first empirical applications were attempts to estimate the impact of nonpharmaceutical polices introduced to fight the spread of Covid-19. As Goodman-Bacon and Marcus (2020) point out, given the differences in timings and locations of different policies, a difference-in-differences (DD) approach would appear to be the most appropriate research design to estimate the causal effects of interventions (such as lockdowns and social distancing). The same argument applies to studies that want to estimate the 
potential environmental impact of Covid-19. For example, if one wanted to understand the impact of lockdowns on local air pollution one could examine differences in air pollution that result from lockdowns in one region compared to other regions in in the same or different countries.

However, as Goodman-Bacon and Marcus (2020) argue, a DD approach in a Covid19 setting, is susceptible to a number of validity concerns that may bias the results that are worth repeating in this paper. Despite these methodological challenges, GoodmanBacon and Marcus point out that a number of papers using a DD design have already being published in one form or another. For example, Fang et al. (2020) examine how mobility restrictions helped reduce the spread of Covid-19 in China while (Friedson et al. 2020) examine the effectiveness of shelter-in-place policies in California. Similar but broader studies also using a DD approach include(Dave et al. (2020); Hsiang et al. (2020); Gupta et al. 2020).

The other popular use of a DD design has been to examine the impact of Covid19 lockdowns on local air pollution. One reason for undertaking such an analysis is to be able to understand the health impacts of reduced pollution levels and Covid-19 presents a unique experimental setting due to the abrupt nature of the intervention. Although a lockdown is an extreme case studies in this area can provide information on the possible health benefits from a range of environmental policies including congestion charging, more cycle lanes, or the permanent or temporary closure of polluting businesses. Research that has examined the impact of Covid-19 on air pollution include (Dutheil et al. 2020; Alomnd et al. 2020; Cole et al. (2020a)). Despite using different (but related) methods, both Alomnd et al. (2020) and Cole et al. (2020a) find significant reductions in NO2 in the areas around Wuhan but surprisingly little effect on a range of other pollutants. The former study uses a DD approach to estimate a model that takes into account annual differences in air quality and the expected drop in pollution due to the Lunar New Year in China that happened just before lockdowns started. They also recast their data to undertake an "event study".

However, researchers should be aware that the validity of a DD design is heavily reliant on how the treatment and control groups are derived. This poses a number of challenges for researchers to overcome when using Covid-19 as a treatment in an environmental setting. Goodman-Bacon and Marcus (2020) provide a list of seven challenges that need to be considered and although these are general, they generally hold in an environmental context. For example, it one was to examine the impact on air pollution between two cities that implemented a lockdown at different times, one would need to be cognisant of a number of different factors that are excellently described by Goodman-Bacon and Marcus (2020). The Goodman-Bacon and Marcus (2020) factors and summarised briefly here:

(1) Packaged policies - when other policies are introduced at the same time or during a lockdown, such as decreasing environmental enforcement activities, even if lockdowns where instigated at different times;

(2) Reverse causality - the timing of any lockdown may be dependent on previous per capita infection rates. This should be less of an issue for most environmental research questions;

(3) Voluntary precautions - people see what happened in other cities of countries and pre-emptively changed their behaviour. For example, people may drive less ahead of a lockdown because they are self-isolating or being generally cautious and hence reducing emissions below usual levels before a lockdown is introduced; 
(4) Anticipation - when governments announce that a lockdown will happen ahead of the actual date. In the context of an air pollution story, and in contrast with the voluntary precautions concern, it is possible that people increased how often they went driving ahead of lockdown as a way of stocking up with supplies or paying final visits to relatives, thus worsening pre-lockdown emission levels so a lockdown then appears to have a stronger emissions reduction effect;

(5) Spillovers - neither the virus nor emissions respect national and state borders. As such, pollution from one city may be blown to neighbouring cities, irrespective of their lockdown status. This means a lockdown in one city may affect pollution levels in other cities not in lockdown;

(6) Variation in policy timing - using unit and time effects and a dummy for when that city had a lockdown would be usual approach in DD studies but, as Goodman-Bacon and Marcus (2020) explain, when treatments are staggered over time and the treatment effects also vary over time, then two-way fixed effects will be biased away from the sign of the true treatment effect. In the case of air pollution this may be less of a concern but it is still possible that pollution levels fell dramatically after the initial lockdown and then slowly increased as lockdown conditions were gradually relaxed. However, these trends may still differ between cities;

(7) Measurement and scaling of the dependent variable - should one use logs, rates, or counts. The choice depends on how the common trend assumption is examined. When measuring infection rates this is also complicated by measurement error. This should be less of an issue with measures of pollution but still relies on the data being accurately collected and recorded in times of lockdown. Such a problem plagues other studies of the impact of disasters on local areas.

Goodman-Bacon and Marcus (2020) go on to present a number of DD specific recommendations. One solution suggested by Cole et al. (2020a) in a study of the impact of Covid19 lockdown in Wuhan on air pollution, is to use an augmented synthetic control model (ASCM) first developed by Abadie and Gardeazabal (2003). Such a methods addresses a number of the Goodman-Bacon and Marcus concerns and is most often used in labour, development and health economics. Synthetic control is similar to traditional DD but uses a data driven process to that uses a weighted-average of a group of controls to reproduce the trajectory of the treatment unit to construct a "artificial" treatment unit. The augmentation of the SCM ( Ben-Michael et al. 2019) allows the researcher to deal with those cases where a good pre-intervention match cannot be found between the treatment and control groups.

A second empirical approach is to use more traditional time series and panel data methods. For example, Dergiades et al. (2020) assess the quantitative impact of government interventions on daily Covid-19 related deaths across 32 countries using a dynamic panel estimation. Likewise, Chen and Qiu (2020) estimate an epistemological dynamic panel model across nine countries to show how economic damage can be limited if citizens wear masks are obey certain quarantine rule. More specifically, the Dergiades et al. (2020) use a Perron and Yabu (2009a) test to endogenously determine when there is a break in a linear trend of the log of deaths per country and then estimate the slope of this trend following Perron and Yabu (2009b). By looking at how government intervention impacts the trend slope shaped by daily deaths they find that an increase in the strength of government intervention at an early stage is the way to achieve an insignificant trend in daily deaths. Such methods could, for example, be applied to high frequency air pollution or other 
environmental data to look for, for example, mortality and morbidity rates due to variation in daily emissions (see Peng et al. 2006 for an early review).

Another way that infection rates have been modelled is through the use of spatial econometrics. For example, Krisztin et al. (2020) use Bayesian spatial econometric techniques to examine the impact of spatial spillovers on infection rates (number of flight connections, trade patterns, common borders etc.). Their main finding was that international flight linkages were the main transmission channel. The spatial approach is also able to show how national travel bans very able to reduce county to country spillovers. In future environmental related research, such an approach could be applied to measuring the impact of lockdowns on air pollution as previously highly connected economies slow down together as a result of both supply and demand shocks.

A related strand of research is whether living in a polluted city increases the fatality rate among residents following exposure to the Covid-19 virus. Early evidence suggests that long-term exposure to air pollution could be an important contributor to high fatality rates (see e.g. Conticini et al. 2020, Ogen 2020, Setti et al. 2020, Travaglio et al. 2020, Wu et al. 2020). For example, Cole et al. (2020b) find, in a study of municipalities in the Netherlands, that those regions with higher levels of PM2.5 emissions experience more Covid-19 cases, more hospital admissions and a higher number of fatalities. Similarly, as noted previously, Persico and Johnson (2020) use a differences in differences design to show that the EPA regulation rollback not only led to an increase in pollution but that cases and deaths increased in rollback areas by 38.8 and $19.1 \%$ respectively. What is important in such studies is to be able to rule out other confounders and any cross-sectional interdependence. For example, more polluted cities tend to have higher pollution densities increasing the likelihood of getting the virus but also the likelihood of receiving a high viral load. Ideally, one should really take into account individual characteristics such as age and ethnicity to be able to estimate the true effect of different air pollutants on health outcomes. This is a fruitful area of future research. ${ }^{17}$

Finally, an area of research that directly links Covid-19 and the environment more broadly is to examine how the spread of Covid-19 is influenced by the climate. The World Health Organisation (2020) ${ }^{18}$ published advice in March 2020 that the virus can be transmitted in areas with hot and humid climates. Any study of this type faces the challenge of overcoming the issue of alternative confounders that may be correlated with temperature. For example, Chen et al. (2020) run a simple regression of Covid-19 cases against distance from the equator and a number of other country level controls such as income, testing intensity, distance to Wuhan, urbanization among others. Results suggest that onedegree increase in absolute latitude is associated with an increase in the number of cases per million people of around $2.6 \%$. The implication is that the Northern hemisphere might be lulled into a false sense of security by falling case numbers in the summer only to see a resurgence of cases once winter returns. However, Yao et al. (2020) find no association between temperature or UV radiation and transmission rates across China. Similarly, Prata et al. (2020), using a polynomial (cubic) regression find no evidence that increases in temperature above $25.80 \mathrm{C}$ reduce the number of Covid-19 cases for sub-tropical Brazil. In

\footnotetext{
${ }^{17}$ It is interesting that neither Cole et al. (2020b) for the Netherlands or Carozzi et al. (2020) for the US find no link is made between urban density and COVID-19 cases and deaths although in the latter case density did influence the timing of the outbreak.

18 https://www.who.int/emergencies/diseases/novelcoronavirus-2019/advice-for-public/myth-busters.
} 
contrast, Farhan et al. (2020) do find a correlation between average temperature, minimum temperature and air quality when they look only at New York.

What is clear from the rapid growth in the literature is that more research is needed to disentangle biological factors from behavioural factors. For example, in hotter countries people may go out less so there is a lower transmission rate. Other climatic factors may also play a role such as humidity, heat, altitude, sunlight intensity and rain. As previously discussed, Chen et al. (2020) also point to other factors such as air pollution might play a role in how many Covid-19 cases are recorded. There is clearly room for a carefully designed study of the various inter-relationships between environmental factors and the impact of Covid-19 on different countries and populations.

\section{Conclusions}

In this article we have discussed some of the lessons from the, currently still ongoing, Covid-19 crisis for research in environmental economics. We decided to emphasize three major areas, namely globalization and cooperation, the green transition and pricing carbon externalities, issues related to uncertainty and timing and, finally, what lessons we would inform future empirical research. We feel that quite a few of the lessons from the Covid-19 crisis are relevant for our future research agenda. Hence, we take the opportunity to very briefly revisit our main lessons from the Covid-19 crisis and link these to our research suggestions.

First, the Covid-19 crisis has shown us that international cooperation easily breaks down during a crisis, and that without global cooperation the costs for the poorer or less able countries may be very high. A fundamental question for future research is, thus, whether we can improve our understanding of the political economy issues that go into cooperation during crisis times. In addition, how can we address the increasing inequalities and how do they impact environmental quality or the ability to address environmental problems?

Second, we have seen that a global crisis easily disrupts international supply chains which, among other effects, has already led to reductions in both the flows of trade as well as people around the world. What is the implication of this both for economic development, but also for environmental quality? In particular, will we see an increase in pollution havens, or a return of the dirty industry to the developed countries? Will we see an increased migration to developed countries that are more able to cope with many types of crises? Will this increased migration increase environmental pressures in the developed world?

Third, the emission reductions from the lockdowns so far appear to be rather small. This suggests that even a large-scale reduction in our economic activities are not able to bring us much closer to minimizing climate change to $1.5^{\circ} \mathrm{C}$ warming. This suggests a need for a much deeper social change coupled with a green transformation that decouples economic activity and carbon emissions. We still lack a clear understanding of how such an economy could look like.

Fourth, there is willingness to finance a post-crisis green stimulus, but there are issues with elevated levels of government debt and determining what really is a greener or browner investment that deserves to be part of the stimulus. Furthermore, is it not clear whether it is possible to design the stimuli in such a way as to reduce inequality, something that was not taken into account in the aftermath of the 2008 financial crisis. 
Fifth, the timing and preparedness of policy interventions is decisive. We have seen that countries that started their lockdowns relatively late (e.g. Italy, UK) have seen more casualties than other countries that were prepared for a potential pandemic (e.g. Taiwan). As researchers we should, therefore, pay more attention to the possible costs of delays, such as in the case of climate action, and understand better how it is possible to fit international interests within national decision taking.

Lastly, the lockdowns everywhere across the world have shown that uncertainty is a big problem for policy making. Thus, information provision is a key and learning decisive. While misinformation, disinformation and malinformation are abundant (Baines and Elliott 2020), expectations still drive policy (e.g. lifting lockdowns despite relatively high death rates). Lobbying, from any side, is thus a serious problem especially if there is one dominant lobby group pursuing mostly own interests. Especially in light of the recent rollbacks of environmental regulations in the US, we need to further our understanding as to how lobbying impacts environmental policy across the world. We also need to put much more effort into investigating the costs and benefits of regulations and potential regulatory rollback in order to help guide informed policy making.

As a final, more personal note, we feel that one of the main lessons from the Covid-19 crisis is that it offers the opportunity for society to push forward a green transition more quickly than might otherwise have happened due to the temporary undermining of incumbent interests and with a general public that remains inherently in favour of policies that reduce pollution and mitigate climate change. However, experience has shown that, once disasters have been overcome, individuals are very keen to return to their profligate ways. The pandemic offers a chance for action, but that opportunity may be fleeting. As our suggestive research agenda has shown, we do not yet have all the answers to provide the best policy advise for every possible question or problem. Nevertheless, we have the tools and methods to do so, and we should become much more active to promote policies that help inform optimal decision taking.

\section{References}

Abadie A, Gardeazabal J (2003) The economic costs of conflict: a case study of the Basque Country. Am Econ Rev 93(1):113-132

Aguirre AA, Catherina R, Frye H, Shelley L (2020) Illicit wildlife trade, wet markets, and COVID-19: preventing future pandemics. World Med Health Policy. https://doi.org/10.1002/wmh3.348

Albers HJ, Lee KD, Rushlow JR, Zambrana-Torrelio C (2020) Disease risk from human-environment interactions: environment and development economics for joint conservation-health policy. Environ Res Econ. https://doi.org/10.1007/s10640-020-00449-6

Aldred J (2012) Climate change uncertainty, irreversibility and the precautionary principle. Camb J Econ 36(5):1051-1072

Allan J, Donovan C, Ekins P, Gambhir A Hepburn C, Reay D, Robins N, Shuckburugh E, Zenghelsi D (2020) A net-sero emissions economic recovery from COVID-10, Oxford Smith School of Enterprise and the Environment Working Paper 20-01

Alomnd D, DU X, Zhang S (2020) Ambigous pollution response to COVID-19 in China. MBER working Paper No. 27086

Barry M (2020) Globalization unwound. Has covid-19 killed globalization, The Economist, May 14, 2020, The Economist Today, daily newsletter

Baines D, Elliott RJR (2020) Defining misinformation, disinformation and malinformation: an urgent need for clarity during the COVID-19 infodemic. University of Birmingham Discussion Paper, No, pp 20-06

Barberis N (2013) The psychology of tail events: progress and challenges. Am Econ Rev 103(3):611-16

Barbier E (2020) Greening the post-pandemic recovery in the G20. https://doi.org/10.1007/s10640-02000437-w 
Ben-Michael E, Feller A, Rothstein J (2019) The augmented synthetic control method. Mimeo, University of California Berkeley. https://arxiv.org/pdf/1811.04170.pdf

van Bergeijk P (2020) https://issblog.nl/2020/04/29/covid-19-is-deglobalization-helping-or-hindering-theglobal-economy-during-the-coronavirus-crisis-by-peter-a-g-van-bergeijk/

Bistline JE (2015) Fat-tailed uncertainty, learning, and climate policy. Clim Change Econ 6(2):1550009

Boucekkine R, Aude P, Fabien P (2013) Optimal regime switching and threshold effects. J Econ Dyn Control 37(12):2979-2997

Brock W, Xepapadeas T (2020) The economy, climate change and infectious diseases: links and policy implications. Environ Res Econ. https://doi.org/10.1007/s10640-020-00442-z

Burke J, Fankhauser S, Bowen A (2020) Pricing carbon during the economic recovery from the COVID-19 pandemic. London: Grantham Research Institute on climate change and the environment and centre for climate change economics and policy, London School of Economics and Political Science. http:// www.lse.ac.uk/GranthamInstitute/publication/pricing-carbon-during-the-economic-recovery-fromthe-covid-19-pandemic/

Burns C, Tobin Eckersley PP (2020) 11EU environmental policy in times of crisis. J Euro Public Policy 27(1):1-19

Calmette MF (2020) Globalization: the day after, TSE Magazine special issue Spring, pp 20-22

Caparrós A, Finus M (2020) Public good agreements under the weakest? Link technology. J Public Econ Theory 22(3):555-582

Carozzi F, Provenzano S, Roth S (2020) Urban density and COVID-19, IZA discussion paper 13440. http:// ftp.iza.org/dp13440.pdf

Chen S, Prettner MK, Geldsetzer P, Wang C, Bärnighausen T, Bloom DE (2020) COVID-19 and climate: global evidence from 117 countries. MedRxiv. https://doi.org/10.1101/2020.06.04.20121863

Chen X, Qiu Z (2020) Scenario analysis of non-pharmaceutical interventions on global Covid-19 transmissions. Covid Econ 46-67. arXiv:2004.04529v2

Chudik A, Pesaran MH, Rebucci A (2020) Voluntary and mandatory social distancing: evidence on COVID19 exposure rates from Chinese Provinces and selected countries. CESifo Working Paper No. 8243

Cole M, Elliott RJR, Liu B (2020a) The impact of the Wuhan Covid-19 lockdown on air pollution and health: a machine learning and augmented synthetic control approach. University of Birmingham Discussion Paper 20-09

Cole M, Ozgen C, Strobl E (2020b) Air pollution exposure and Covid-19, IZA Discussion paper (forthcoming)

Conticini E, Frediani B, Caro D (2020) Can atmospheric pollution be considered a co-factor in extremely high level of SARS-CoV-2 lethality in Northern Italy? Environ Pollut 261:114465. ISSN 0269-7491

Cosbey A, Droege S, Fischer C, Munnings C (2019) Developing guidance for implementing border carbon adjustments: lessons, cautions, and research needs from the literature. Rev Environ Econ Policy 13(1):3-22

Diaz D, Moore F (2017) Quantifying the economic risks of climate change. Nat Clim Change 7(11):774-782

Dietz S, Venmans F (2019) Cumulative carbon emissions and economic policy: in search of general principles. J Environ Econ Manag 96(2019):108-129

Dockery M, Bawa S (2020) Working from home in the COVID-19 lockdown. Bankwest Curtin Economics Centre, Bentley

Dutheil F, Baker JS, Navel V (2020) COVID-19 as a factor influencing air pollution? Environ Pollut 263:114466

Copeland B, Taylor S (2003) Trade and the environment. Princeton University Press, Princeton

Dave D, Friedson AI, Matsuzawa K, Sabia JJ (2020) When do shelter-in-place orders fight COVID-19 best? Policy heterogeneity across states and adoption time, IZA Discussion Paper, p 13190

De Beer P (2012) Earnings and income inequality in the EU during the crisis. Int Labour Rev 151(4):313-331

Dergiades T, Milas C, Panagiotidis T (2020) Effectiveness of government policies in response to the COVID-19 outbreak, SRNN-id3602004

Elkerbout M, Egenhofer C, Ferrer JN, Catuti M, Kustova I, Rizos V (2020) The European green deal after corona-implications for EU climate policy. No. 26869. Centre Eur Policy Stud

Fang H, Wang L, Yang YY (2020) Human mobility restrictions and the spread of the novel Coronavirus (2019-nCoV) in China. NBER Working Paper 26906

Friedson AI, McNichols D, Sabia JJ, Dave D (2020) Did California's shelter-in-place order work? Early Coronavirus-related public health effects. NBER Working Paper 26992

Farhan Bashir M, Ma B, Bushra Komal B, Adnan Bashir M, Tan D, Bashir M (2020) Correlation between climate indicators and COVID-19 pandemic in New York, USA. Sci Total Environ 728:138835. ISSN 0048-9697 
Gardiner B (2020) Why COVID-19 will end up harming the environment, National Geographic. https:// www.nationalgeographic.co.uk/environment-and-conservation/2020/06/why-covid-19-will-end-upharming-the-environment

Gerlagh R, Heijmans R, Rosendahl K (2020) COVID-19 tests the market stability reserve. Forthcoming Environ Res Econ. https://doi.org/10.1007/s10640-020-00441-0

Gibney E (2020) Whose coronavirus strategy worked best? Scientists hunt most effective policies. Nature 581:15-16

Giovanniello M, Perroni C (2020) Climate change and pandemics: on the timing of interventions to preserve a global common. CAGE Online Working Paper Series 467, Competitive Advantage in the Global Economy (CAGE)

Goodman-Bacon A, Marcus J (2020) Using difference-in-difference to identify causal effects of COVID-19 policies. DIW Berlin Discussion Paper No. 1870. https://doi.org/10.2139/ssrn.3603970

Gollier C, Straub S (2020) Coronavirus and the value of human life, TSE Magazine special issue Spring, pp 28-33. Also at https://www.tse-fr.eu/economics-coronavirus-some-insights

Gopinath G (2020) https://europeansting.com/2020/05/21/how-we-can-survive-the-great-covid-lockdownimf-chief-economist-gita-gopinath/. Consulted June 6, 2020

Greaker M, Heggedal T-R, Rosendahl KE (2018) Environmental policy and the direction of technical change. Scand J Econ 120(4):1100-1138

Gruszczynski L (2020) The COVID-19 pandemic and international trade: temporary turbulence or paradigm shift? Euro J Risk Regul 11(2):337-342

Gupta S, Montenovo L, Nguyen TD, Rojas FL, Schmutte IM, Simon KI, Weinberg BA, Wing C (2020) Effects of social distancing policy on labor market outcomes. NBER Working paper No. 27280

Helm D (2020) September 2020 (and March 2021): the temporary and the permanent impacts of coronavirus

Hepburn C, O'Callaghan B, Stern N, Stiglitz J, Zenghelis D (2020) Will COVID-19 fiscal recovery packages accelerate or retard progress on climate change? Working paper 20-02 Oxford Smith School of Enterprise and the Environment. Forthcoming Oxford Rev Econ Policy, vol 36 (S1)

Holmberg A, Alvinius A (2020) Children's protest in relation to the climate emergency: a qualitative study on a new form of resistance promoting political and social change. Childhood 27(1):78-92

Howarth C, Bryant P, Corne A, Fankhauser S, Gouldson A, Whitmarsh L, Willis R (2020) Building a social mandate for climate action: lessons from COVID-19. Forthcoming Environ Res Econ

Hsiang S, Allen D, Annan-Phan S, Bell K, Bolliger I, Chong T, Druckenmiller H, Huang LY, Hultgren A, Krasovich E, Lay P, Lee J, Rolf E, Tseng J, Wu T (2020) The effect of large-scale anticontagion policies on the Coronavirus (COVID-19) pandemic. Working Paper. https://doi. org/10.1101/2020.03.22.20040642. Accessed 10 May 2020

IEA (2020) World energy investment 2020, IEA, Paris. https://www.iea.org/reports/world-energy-inves tment-2020

IMF (2020) World Economic Outlook Update June 2020, International Monetary Fund, Washington D.C.

IPCC (2018) Summary for Policymakers. In: Masson-Delmotte V, Zhai P, Pörtner H-O, Roberts D, Skea J, Shukla PR, Pirani A, Moufouma-Okia W, Péan C, Pidcock R, Connors S, Matthews JBR, Chen Y, Zhou X, Gomis MI, Lonnoy E, Maycock T, Tignor M, Waterfield T (eds) Global Warming of $1.5^{\circ} \mathrm{C}$. An IPCC Special Report on the impacts of global warming of $1.5^{\circ} \mathrm{C}$ above pre-industrial levels and related global greenhouse gas emission pathways, in the context of strengthening the global response to the threat of climate change, sustainable development, and efforts to eradicate poverty . World Meteorological Organization, Geneva, pp 32

Ipsos (2020) How do Great Britain and the world view climate change and Covid-19?, Ipsos surveys Opinion Poll Report No. Global Advisor wave 139 (GA 139), Ipsos, Paris

Isaifan RJ (2020) The dramatic impact of Coronavirus outbreak on air quality: has it saved as much as it has killed so far? Glob J Environ Sci Manag 6(3):275-288

Jensen S, Traeger CP (2014) Optimal climate change mitigation under long-term growth uncertainty: stochastic integrated assessment and analytic findings. Euro Econ Rev 69:104125

Jones M, Sugden R (2001) Positive confirmation bias in the acquisition of information. Theory Decision 50(1):59-99

Jorda O, Singh SR, Taylor AM (2020) Longer-run economic consequences of pandemics. Covid Econ. https ://doi.org/10.3386/w26934

Kallis G (2011) In defence of degrowth. Ecol Econ 70(5):873-880

Kecinski M, Messer KD, McFadden BR, Malone T (2020) Environmental and regulatory oncerns during the COVID-19 pandemic: results from the pandemic food and stigma survey. Environ Res Econ. https ://doi.org/10.1007/s10640-020-00438-9

Kühne RW (2019) Climate change: the science behind Greta Thunberg and Fridays for future. OSF Preprints. September 2. https://doi.org/10.31219/osf.io/2n6kj 
Krisztin T, Piribauer P, Wogerer M (2020) The spatial econometrics of the coronavirus pandemic. Lett Spat Resour Sci. https://doi.org/10.1007/s12076-020-00254-1

Lipfert FW (2004) Air pollution and poverty: does the sword cut both ways? J Epidemiol Commun Health $58(1): 2-3$

Mäler KG, Anastasios Xepapadeas A, Aart De Zeeuw A (2003) The economics of shallow lakes. Environ Res Econ 26(4):603-624

Martin R, Van Reenen J (2020) The case for a COVID-19 carbon tax, https://blogs.lse.ac.uk/covid 19/2020/06/02/the-case-for-a-covid-19-carbon-tax/

Mehra MR, Desai SS, Ruschitzka F, Patel AN (2020) Retraction-hydroxychloroquine or chloroquine with or without a macrolide for treatment of COVID-19: a multinational registry analysis. Lancet. https://doi. org/10.1016/S0140-6736(20)31180-6

Mendelsohn R, Dinar A, Williams L (2006) The distributional impact of climate change on rich and poor countries. Environ Develop Econ 11(2):159-178

Müller-Fürstenberger G, Schumacher I (2017) The consequences of a one-sided externality in a dynamic, two-agent framework. Eur J Oper Res 257(1):310-322

Myllyvirta L (2020) Analysis: Coronavirus temporarily reduced China's $\mathrm{CO}_{2}$ emissions by a quarter. Carbonbrief. https://www.carbonbrief.org/analysis-coronavirus-has-temporarily-reduced-chinas-co2emissions-by-a-quarter. Accessed 25 Apr 2020

Newbold S, Finnoff, D. Thunstrom, L. Ashworth, M. and Shogren, J. F. (2020), Effects of physical distancing to control COVID-19 on public health, the economy, and the environment. Available at SSRN 3631029 (2020)

Nordhaus W (2014) Estimates of the social cost of carbon: concepts and results from the DICE-2013R model and alternative approaches. J Assoc Environ Res Econ 1(1/2):273-312

Ogen Y (2020) Assessing nitrogen dioxide (NO2) levels as a contributing factor to coronavirus (COVID-19) fatality. Sci Total Environ 726:138605

Papanikolaou D, Schmidt LDW (2020) Working remotely and the supply-side impact of Covid-19. No. w27330. Natl Bureau Econ Res. https://doi.org/10.3386/w27330

Peng RD, Dominici F, Louis TA (2006) Model choice in time series studies of air pollution and mortality. J Royal Stat Soc Series A 169(2):179-203

Persico C, Johnson KR (2020) The effects of increased pollution on COVID-19 cases and deaths. http://ssrn. com/abstract $=3633446$

Perron P, Yabu T (2009a) Testing for shifts in trend with an integrated or stationary noise component. J Bus Econ Stat 27:369-396

Perron P, Yabu T (2009b) Estimating deterministic trends with an integrated or stationary noise component. J Econ 151:56-69

Piketty T (2018) https://www.rug.nl/feb/blog/thomas-piketty-on-inequality-and-globalisation-17-07-2018

Prata DN, Rodrigues W, Bermejo PH (2020) Temperature significantly changes COVID-19 transmission in (sub)tropical cities of Brazil. Sci Total Environ 729:138862 ISSN 0048-9697

Quaas MF, Meya J, Schenk H, Bos B, Drupp MA, Requate T (2020) The social cost of contacts: theory and evidence for the COVID-19 pandemic in Germany. Available at SSRN 3606810

Ramelli S, Wagner AF (2020) Feverish Stock Price Reactions to COVID-19. Swiss Finance Institute Research Paper 20-12

Research and Degrowth (2010) Degrowth declaration of the Paris 2008 conference. J Clean Prod 18:523-524

Samet JM, Burke TA (2020) Deregulation and the assault on science and the environment. Ann Rev Public Health 41:347-361

Schumacher I (2009) Endogenous discounting via wealth, twin-peaks and the role of technology. Econ Lett 103(2):78-80

Schumacher I, Elliott RJR, Perez-Barahona A, Withagen C (2020) The Covid-19 crisis must not undermine the green transition. Opinions, Sustain Future Policy Lab, pp 2020-002

Setti LF, Passarini F, Gennaro GD, Barbieri P, Perrone MG, Piazzalunga A, Borelli M, Palmisani J, Di Gilio A, Piscit Miani A (2020) The potential role of particulate matter in the spreading of COVID-19 in Northern Italy: first evidence-based research hypothesis. MedRxiv. https://doi. org/10.1101/2020.04.11.20061713

Sforza A, Steininger M (2020) Globalization in the time of COVID-19. CESifo working paper 8184

Shih W (2020) Is it time to rethink globalized supply chains? MITSloan Management Review. https://sloan review.mit.edu/article/is-it-time-to-rethink-globalized-supply-chains/

Shope R (1991) Global climate change and infectious diseases. Environ Health Perspect 96:171-174

Sirkeci I, Yucesahin MM (2020) Coronavirus and migration: analysis of human mobility and the spread of COVID-19. Migr Lett 17(2):379-398 
Sorman AH, Giampietro M (2013) The energetic metabolism of societies and the degrowth paradigm: analyzing biophysical constrains and realities. J Clean Prod 38:80-93

Steger TM (2005) Stochastic growth under Wiener and Poisson uncertainty. Econ Lett 86(3):311-316

Stern N, Unsworth S, Valero A, Zenghelis D, Rydge J, Robins N (2020) Strategy, investment and policy for a strong and sustainable recovery: an action plan, CEP paper number 005

Sterner T (2012) Distributional effects of taxing transport fuel. Energy Policy 41:75-83

Teale C (2020) COVID-19 may sport the thinnest silver lining: a cleaner climate. Smart Cities Dive

Tirole J (2020) Rebuilding the world after Covid-19”, TSE Magazine special issue Spring, pp 17-19

Tol RSJ (2009) The economic effects of climate change. J Econ Perspect 23(2):29-51

Travaglio M, Yu Y, Popovic R, Selley L, Santos Leal N, Martins LM (2020) Links between air pollution and COVID-19 in England. MedRxiv. https://doi.org/10.1101/2020.04.16.20067405

Treasury HM (2020) The Dasgupta review independent review on the economics of biodiversity interim report. April. Recuperado desde https://www.gov.uk/government/publications/interim-reportthedasgupta-review-independent-review-on-the-economics-of-biodiversity

UNEP (2019) Emissions Gap Report 2019. Executive summary. United Nations Environment Programme, Nairobi

Van Bavel JJ, Baicker K, Boggio PS, Capraro V, Cichocka A, Cikara M, Crockett MJ, Crum AJ, Douglas KM, Druckman JN, Drury J (2020) Using social and behavioural science to support COVID-19 pandemic response. Nat Human Behav 4:460-471. https://doi.org/10.1038/s41562-020-0884-z

Vanham P (2019) World Economic Forum https://www.weforum.org/agenda/2019/01/how-globalization-40 -fits-into-the-history-of-globalization

Weiss M, Cattaneo C (2017) Degrowth-taking stock and reviewing an emerging academic paradigm. Ecol Econ 137:220-230

Weitzman ML (2009) On modeling and interpreting the economics of catastrophic climate change. Rev Econ Stat 91(1):1-19

WTO (2020) https://www.wto.org/english/tratop_e/covid19_e/faqcovid19_e.htm. Consyulted June 6, 2020

Wu X, Nethery RC, Sabath BM, Braun D, Dominici F (2020) Exposure to air pollution and COVID19 mortality in the United States: a nationwide cross-sectional study. MedRxiv. https://doi. org/10.1101/2020.04.05.20054502

Yao Y, Pan J, Liu Z, Meng X, Wang W, Kan H, Wang W (2020) No association of COVID-19 transmission with temperature or UV radiation in Chinese cities. Eur Respir J 55:2000517. https://doi. org/10.1183/13993003.00517-2020

Zachmann, G. and McWilliams, B. (2020), A Europrean carbon border tax: much pain, little gain, Policy Contribution 05/2020, Bruegel

Publisher's Note Springer Nature remains neutral with regard to jurisdictional claims in published maps and institutional affiliations. 